\title{
Subclinical intramammary infection does not affect bovine milk ethanol stability
}

\author{
Infecção intramamária subclínica \\ não afeta a estabilidade do leite bovino
}

\author{
Cristian Marlon de Magalhães Rodrigues MARTINS'1; Juliano Leonel GONÇALVES'1; \\ Bruna Gomes ALVES ${ }^{1}$; Marcos André ARCARI ${ }^{1}$; Marcos Veiga dos SANTOS ${ }^{1}$
}

${ }^{1}$ Universidade de São Paulo, Faculdade de Medicina Veterinária e Zootecnia, Departamento de Nutrição e Produção Animal, Pirassununga - SP, Brazil

\begin{abstract}
The present study hypothesized that intramammary infection (IMI) might reduce milk ethanol stability (MES), mainly when IMI is caused by major pathogens. Thus, this study evaluated the effect of IMI on bovine MES using a natural exposure experimental design. Ninety-four lactating cows from five dairy herds were selected once they were determined to have an IMI, based on milk bacteriological culturing with positive isolation and somatic cell count (SCC) $>200 \times 10^{3}$ cells $/ \mathrm{mL}$ in two out of three composite milk samples collected during three consecutive weeks. After selection, cows were sampled a second time (within two weeks) for evaluation at mammary quarter level $(\mathrm{n}=326)$ : milk yield (kg/quarter/day), MES, composition (fat, protein, lactose, casein, total solids and solids-non-fat), and bacteriologic culture. The effect of subclinical mastitis on MES was tested by two models: 1) comparison of healthy vs. infected quarters; and 2) comparison of contralateral mammary quarter within cow. The only milk composition variable associated with MES was lactose $(r=0.18 ; P<0.01)$. Subclinical IMI did not affect MES when the comparison was performed using both models (1 and 2). Likewise, MES did not change when infected quarters were sorted into two groups of pathogens (major, minor and infrequent; and contagious, environmental, minor and infrequent) and compared with healthy mammary quarters. Considering the results of both models, subclinical IMI did not affect MES of dairy cows.
\end{abstract}

Keywords: Alcohol test. Casein. Ionic calcium. Mastitis.

\section{Resumo}

Neste trabalho investigou-se a hipótese de que a infecção intramamária (IIM) poderia reduzir a estabilidade do leite ao etanol (ELA), principalmente quando a IIM é causada por agentes primários. Assim, em um experimento de exposição natural, foi avaliado o efeito da IIM sobre a ELA em bovinos. Noventa e quatro vacas em lactação de cinco rebanhos leiteiros foram selecionadas por apresentar IIM, segundo resultados de cultura bacteriológica de amostras compostas de leite (isolamento positivo) e contagem de células somáticas (CCS) $>200 \times 10^{3}$ células $/ \mathrm{mL}$ em pelo menos duas de três coletas semanais consecutivas. Após essa seleção, as vacas foram amostradas pela segunda vez (dentro de duas semanas) para avaliação da IIM em amostras de leite coletadas por quarto mamário $(\mathrm{n}=326)$ : produção de leite ( $\mathrm{kg} /$ quarto/dia), ELA, composição (gordura, proteína, lactose, caseína, sólidos totais e sólidos não gordurosos) e cultura bacteriológica. $\mathrm{O}$ efeito da mastite subclínica sobre a ELA foi testada por dois modelos: 1) comparação de quarto sadio versus infectado; e 2) comparação de quartos mamários contralaterais. A única variável de composição do leite associada à ELA foi a lactose $(\mathrm{r}=0,18 ; \mathrm{P}<0,01)$. A IIM subclínica não afetou a ELA quando a comparação foi realizada utilizando-se os dois modelos (1 e 2); bem como a ELA não foi alterada quando os quartos infectados foram classificados em grupos de agentes patogênicos (primários, secundários e infrequentes; ou contagiosos, ambientais, secundários e infrequentes) e comparados com os quartos mamários sadios. Os resultados obtidos com os dois modelos empregados demonstraram que a IIM subclínica não afetou a ELA de vacas leiteiras. Palavras-chave: Teste do álcool. Caseína. Cálcio iônico. Mastite.

Correspondence to:

Marcos Veiga dos Santos

Universidade de São Paulo, Faculdade de Medicina Veterinária e Zootecnia, Departamento de Nutrição e Produção Animal

Av. Duque de Caxias Norte, 225 - Jardim Elite

CEP 13635-900, Pirassununga, SP, Brazil

e-mail:mveiga@usp.br

Received: 6/8/2017

Approved: 13/1/2018

\section{Introduction}

Milk ethanol stability (MES) is one of the main farm tests used for estimation of milk stability in tropical regions before milk transportation and upon delivery of the milk to dairy factories (FISCHER et al., 2012). MES is used for indirect estimation of the milk acidity that causes casein destabilization (coagulation) during reaction 
with ethanol solution and to predict the heat stability of milk proteins during milk heat processing. Besides milk acidification, MES can be affected by other factors such as mineral deficiencies or imbalances (mainly $\mathrm{Ca}, \mathrm{P}$ and $\mathrm{Mg}$ ) or some changes in the cow's diet, which cause the unstable non-acid milk (Unam) (ZANELA et al., 2006). High incidences of Unam have been reported in other studies, which resulted in significant economic losses to the dairy industry, especially in countries using ultra-high temperature (UHT) as the main form for fluid milk processing (CHAVEZ et al., 2004; FISCHER et al., 2012; OLIVEIRA et al., 2013).

In non-acid milk, the concentration of ionic calcium (iCa) was the main milk component associated with the unstable milk caseins (BARROS et al., 1999). The increase of milk concentrations of iCa may reduce the negative charges of the casein micelles and the strength of electrostatic repulsion between them, which reduces the casein resistance to coagulation during contact with ethanol or milk heat processing (BARROS et al., 1999). Previous studies reported that feed restriction (BARBOSA et al., 2012; STUMPF et al., 2013) and metabolic disorders associated with blood acid-base changes (MARQUES et al., 2011; FAGNANI et al., 2014; MARTINS et al., 2015) of dairy cows could be followed by increased milk concentration of iCa and reduced stability of milk proteins. Other milk characteristics were also associated with a lower stability, such as changes in concentrations of caseins' subunits and $\beta$-lactoglobulin, milk urea nitrogen (MUN), temperature of the milk sample during analysis, $\mathrm{pH}$, and concentrations of citrate and phosphate (JEURNINK; KRUIF, 1995; SINGH, 2004; LEWIS, 2011).

Mastitis has been also associated with changes in milk components (e.g., concentrations of lactose and proteins) as well as changes in concentrations of milk ions (LEITNER et al., 2006). Milk from mastitis-infected cows and milk from late lactation cows were three times more likely to be unstable to MES test compared to the milk from healthy cows at mid-lactation (TSIOULPAS et al., 2007; FISCHER et al., 2012). This instability can be associated with changes in milk $\mathrm{pH}$ and higher permeability of mammary quarter epithelium, which allows ions to pass from bloodstream to milk, which increases the concentration of iCa (HOLT, 2004). However, Fischer et al. (2012) stated that there are no evidences that mastitis directly affects MES. On the other hand, Oliveira et al. (2013) reported that low SCC milk was more stable at the ethanol test than high SCC milk. These controversial results of the effect of mastitis over the milk stability can be related to different responses of some specific microorganisms that cause intramammary infection (IMI) and, consequently, alter the mammary gland epithelium and milk composition.

Therefore, in the present investigation, the hypothesis was that subclinical IMI reduces MES by the alteration of milk composition, mainly when it is caused by major pathogens. To test this hypothesis, the present study evaluated the effect of IMI on MES by comparing infected and healthy mammary quarters of dairy cows.

\section{Material and Methods}

\section{Dairy herds and cow selection}

Before selection for the present study, the herds were required to have cow's identification and data recording systems and had to apply a mastitis control program recommended by the National Mastitis Council (NMC). This included consistent use of pre- and post-milking teat dipping, application of dry cow therapy, periodic milking machine maintenance, and proper milking and intramammary treatment procedures.

All lactating cows were housed in free-stall barn facilities and milked in parlors twice a day, using similar milking routine among farms. In all herds, cows were fed a total mixed ration (TMR) composed of corn silage, grain concentrate, and minerals. Water was available ad libitum. The average milk yield of enrolled farms was $22.9 \pm 10.2 \mathrm{~L} /$ cow/day during the sampling period. The study covered a nine-month period (February to October 2014) in two steps.

Step 1: composite milk samples were collected from all lactating cows without clinical mastitis history, from 5 Brazilian dairy herds (located in the Midwest area of São Paulo State), for milk composition (concentration of milk protein and fat) and SCC analyses (GONÇALVES, 2017; data not shown). Daily milk yield (L/cow/day) was recorded and the information about parity and days in milk (DIM) were also collected from the database of the farms enrolled in the present study. Furthermore, milk samples were submitted to bacteriological culture for mastitis pathogen identification. Dairy cows with SCC $>200 \times 10^{3}$ cells $/ \mathrm{mL}$ and positive for isolated pathogens were considered as subclinically infected $(\mathrm{n}=94)$ and were selected for evaluation at the quarter level within 14 days (Step 2). 
Step 2: quarter milk samples $(n=396)$ were collected from 94 cows selected in Step 1 for bacteriological culture and analyses of MES, milk composition (fat, protein, lactose, casein, total solids and solids-non-fat) and SCC. Mammary quarters were individually milked using a bucket milking system as described by Gonçalves et al. (2016). This milking system allowed the milk to flow separately from each mammary quarter into a bucket. After milking, quarter milk samples $(40 \mathrm{~mL})$ from the milk meter were collected into plastic tubes containing the antimicrobial Bronopol (2-bromo-2-nitropropane-1,3-diol) as preservative $(0.05 \mathrm{~g} / 100 \mathrm{~mL}$ milk). Samples were kept refrigerated $\left(4-7^{\circ} \mathrm{C}\right)$ until transportation to the laboratory for milk composition and SCC analysis.

\section{Microbiological, MES, SCC and milk composition analysis}

Isolation and identification of pathogens in mastitis milk samples were performed according to the methodology proposed by NMC (2004). Approximately $10 \mu \mathrm{L}$ of milk were inoculated in blood agar plate (containing $5 \%$ bovine blood) with the calibrated platinum loop. The plates were aerobically incubated at $37^{\circ} \mathrm{C}$ and checked at 24,48 and $72 \mathrm{~h}$ after inoculation for microbial growth. After the incubation period, colonies were classified according to their morphological features (color, appearance, size and presence of hemolysis). The isolates were Gram stained and differentiated at the species or group level by biochemical tests.

Composite milk samples from daily milking were collected and stored for $12 \mathrm{~h}$ at $5{ }^{\circ} \mathrm{C}$ before determination of MES at the following concentrations (vol/vol): 64, 72, 76 and $80 \%$ ethanol (ZANELA et al., 2006). Results were expressed by the lowest concentration of ethanol in which milk coagulation occurred (MARQUES et al., 2011).

The SCC was determined by flow cytometry using a SCC counter (Somacount $300^{\circ}$, Bentley Instruments Inc., Chaska, MN, USA). Concentrations of milk fat, protein, lactose, casein, total solids and solids-non-fat were determined by infrared absorption, using a milk analyzer (Bentley $2000^{\circ}$, Bentley Instruments Inc., Chaska, MN, USA).

\section{Subclinical mastitis definition}

Mastitis pathogens causing IMI were categorized into minor, contagious, environmental, and infrequent pathogen groups. Mammary quarters were considered to have subclinical mastitis when milk samples had isolation of $>10$ colonies $(1,000 \mathrm{cfu} / \mathrm{mL})$ of minor pathogens (Corynebacterium spp. or coagulase-negative staphylococci, CNS); > 3 colonies $(300 \mathrm{cfu} / \mathrm{mL})$ of environmental pathogens (environmental streptococci or Gram-negative); $\geq 1$ colony $(100 \mathrm{cfu} / \mathrm{mL})$ of contagious pathogens (Staphylococcus aureus or Streptococcus agalactiae) or other pathogens as described by (DOHOO et al., 2011a, 2011b). Coagulase-positive staphylococci (CPS), Enterococcus spp. and yeast were considered infrequent pathogens. Mammary quarters were considered healthy when no bacterial growth was observed after $72 \mathrm{~h}$ of milk incubation.

\section{Statistical analysis at the mammary quarter level}

Pearson correlations and multivariable mixed regression model analysis: first, a Pearson correlation was determined to evaluate the associations among studied variables using the PROC CORR command of Statistical Analysis System Institute (2001). Additionally, a multivariable mixed regression model was performed with PROC MIXED command of SAS (2001) to access the effects of cow's data and milk components on MES, according to the following model:

$$
\begin{aligned}
& \mathrm{Y}(\mathrm{MES})_{\mathrm{ijk} k \mathrm{mnopqrs}}=\mathrm{int}+\beta_{\mathrm{i}}{ }^{\star} \mathrm{P}_{\mathrm{i}}+\beta_{\mathrm{j}}{ }^{\star} \mathrm{DIM}_{\mathrm{j}}+\beta_{\mathrm{k}}{ }^{*} \mathrm{Q}_{\mathrm{k}}+ \\
& +\beta_{1}{ }^{*} \mathrm{MY}_{1}+\beta_{\mathrm{m}}{ }^{*} \mathrm{Fat}_{\mathrm{m}}+\beta_{\mathrm{n}}{ }^{*} \text { Protein }_{\mathrm{n}}+\beta_{\mathrm{o}}{ }^{*} \text { Lactose }_{\mathrm{o}}+ \\
& +\beta_{\mathrm{p}}^{*} \operatorname{Casein}_{\mathrm{p}}+\beta_{\mathrm{q}}{ }^{*} \operatorname{LnSCC}_{\mathrm{q}}+\beta_{\mathrm{r}}^{*} \mathrm{IMI}_{\mathrm{r}}+\mathrm{Cow}_{\mathrm{s}}+ \\
& +\operatorname{Herd}_{\mathrm{t}}+e_{\mathrm{ijklmnopqrs}}
\end{aligned}
$$

$\mathrm{Y}$ is the MES; int is the intercept; $\beta$ refers to the regression coefficient for each outcome; $\mathrm{P} i$ is the parity; DIMj is the days in milk; $\mathrm{Qk}$ is the quarter position; MYl is the daily milk yield; Fatm is the daily fat yield; Proteinn is the daily protein yield; Lactoseo is the daily lactose yield; Caseinp is the daily casein yield; NLSCCq is the natural $\log$ of SCC; IMIr is the fixed effect of IMI at quarter level ( $m=1$ to 5 ; negative, contagious, environmental, minor or infrequent pathogens); Cows is the random effect of cow; Herdi is the random effect of herd; and $e$ is the random error term. Heterogeneity of variances was removed from all SCC data by converting SCC to natural logarithms. For all statistical analyses, significance was declared at $\mathrm{P} \leq 0.05$ and trends at $\mathrm{P} \leq 0.10$.

Statistical analysis for comparison of contralateral mammaryquarters: the effect of subclinical mastitis on MES was evaluated by comparison of contralateral mammary 
quarter using split plot design Gonçalves et al. (2016). This was done by first splitting the anterior and posterior mammary quarters in half and then calculating the difference of all variables evaluated between healthy $v s$. infected contralateral quarter and secondly between healthy quarters $v s$. healthy contralateral quarter. The following statistical model was used:

$$
\begin{gathered}
\Delta \mathrm{Y}_{\mathrm{ijklm}}=\mu+\operatorname{Herd}_{\mathrm{i}}+\mathrm{Q}_{\mathrm{j}}+\mathrm{DIM}_{\mathrm{k}}+\mathrm{P}_{1}+\mathrm{IMI}_{m}+ \\
+\mathrm{Q}_{\mathrm{j}} \times \mathrm{IMI}_{m}+e_{i j k l m}
\end{gathered}
$$

Where $\Delta \mathrm{Y}$ is the difference of each evaluated outcome (MES) between healthy contralateral quarters or between healthy $v s$. infected contralateral quarters; $\mu$ is the overall mean difference; $H_{i}$ is the random effect of herd; $Q_{j}$ is the fixed effect of quarter position ( $j=1$ to 2 ; front and rear quarters split in half); $\mathrm{DIM}_{\mathrm{k}}$ is the days in milk; $\mathrm{P}_{l}$ is the parity; IMI $_{m}$ is the fixed effect of presence or absence of IMI ( $\mathrm{m}=1$ to 5 ; negative, contagious, environmental, minor or infrequent pathogens); $\mathrm{Q}_{\mathrm{j}} \times \mathrm{IMI}_{m}$ is the interaction between the fixed effects of quarter position and infection status, and $e_{\mathrm{ijklm}}$ is the random error term.

\section{Results}

\section{Bacteriological culturing descriptive results}

In Step 1, a total of 650 composite milk samples were collected (GONÇALVES, 2017; data not shown). From this total, 326 mammary quarters from 94 lactating cows were selected for having a pathogen causing subclinical IMI and SCC $\geq 200 \times 10^{3}$ cells $/ \mathrm{mL}$ (Step 2). A total of 45 (45.4\%) lactating cows showed 69 (17.4\%) mammary quarters with culture-positive and quarter SCC averaged $1,188.94 \times 10^{3}$ cells $/ \mathrm{mL}$. The most frequently isolated group of pathogens at the quarter level were minor pathogens $(7.32 \% ; \mathrm{n}=29)$, followed by environmental $(6.56 \%$; $\mathrm{n}=26)$, infrequent $(2.27 \% ; \mathrm{n}=9)$ and contagious $(1.26 \%$; $\mathrm{n}=5$ ). As shown in table 1 , results of bacteria isolation were distributed per MES groups - a) MES $\geq 80$; b) $M E S \geq 72$ and $\mathrm{MES}<80$; and c) $\mathrm{MES}<72$.

Table 1 - Mastitis pathogen frequency of isolation from mammary quarter samples $(n=326)$ in five dairy herds according the milk

\begin{tabular}{|c|c|c|c|c|c|}
\hline \multirow{3}{*}{ Microorganisms } & \multicolumn{3}{|c|}{$N^{0}$ isolates } & \multirow{3}{*}{$\begin{array}{c}\text { Absolute } \\
\text { frequency (\%) }\end{array}$} & \multirow{3}{*}{$\begin{array}{c}\text { Relative } \\
\text { frequency (\%) }\end{array}$} \\
\hline & \multicolumn{3}{|c|}{ LSM$^{1}$ estimate for MES $^{2}$} & & \\
\hline & $\geq 80$ & $\geq 72$ and $<80$ & $<72$ & & \\
\hline No. & 95 & 136 & 95 & $100.00 \%$ & - \\
\hline Negative culture & 81 & 104 & 72 & $78.83 \%$ & - \\
\hline Positive culture & 14 & 32 & 23 & $21.17 \%$ & - \\
\hline Minor pathogens & 3 & 17 & 9 & $8.90 \%$ & $42.03 \%$ \\
\hline Corynebacterium spp. & 2 & 12 & 7 & $6.44 \%$ & $30.43 \%$ \\
\hline Coagulase negative Staphylococci & 1 & 5 & 2 & $2.45 \%$ & $11.59 \%$ \\
\hline Environmental pathogens & 8 & 11 & 7 & $7.98 \%$ & $37.68 \%$ \\
\hline Streptococcus spp. & 7 & 10 & 4 & $6.44 \%$ & $30.43 \%$ \\
\hline Streptococcus bovis & 2 & 4 & 2 & $2.45 \%$ & $11.59 \%$ \\
\hline Streptococcus dysgalactiae & 1 & 0 & 0 & $0.31 \%$ & $1.45 \%$ \\
\hline Streptococcus uberis & 4 & 6 & 2 & $3.68 \%$ & $17.39 \%$ \\
\hline Gram negative bactéria & 1 & 1 & 3 & $1.53 \%$ & $7.25 \%$ \\
\hline Infrequent pathogens & 3 & 3 & 3 & $2.76 \%$ & $13.04 \%$ \\
\hline Coagulase positive staphylococci & 0 & 0 & 1 & $0.31 \%$ & $1.45 \%$ \\
\hline Enterococcus spp. & 2 & 3 & 1 & $1.84 \%$ & $8.70 \%$ \\
\hline Yeast & 1 & 0 & 1 & $0.61 \%$ & $2.90 \%$ \\
\hline Contagious pathogens & 0 & 1 & 4 & $1.53 \%$ & $7.25 \%$ \\
\hline Staphylococcus aureus & 0 & 0 & 1 & $0.31 \%$ & $1.45 \%$ \\
\hline Stretococcus agalactiae & 0 & 1 & 3 & $1.23 \%$ & $5.80 \%$ \\
\hline
\end{tabular}
ethanol stability groups - Pirassununga - 2017

${ }^{1}$ Least squares means; ${ }^{2}$ Milk ethanol stability 


\section{Association between milk components, MES and cow-level information}

Results of Pearson correlation analysis indicated that milk yield and lactose content were positively correlated with MES, whereas the other milk content (fat, protein, casein, TS, SNF), LnSCC and DIM were negatively correlated with MES at the quarter level (Table 2). However, on mixed regression model, considering cows and herds as random effects, LnSCC, DIM and MY had no effect on MES ( $\mathrm{P}=0.445)$, while milk lactose and casein content $(P=0.009)$ and $(P=0.046)$ had positive and negative association with MES, respectively (Table 3).

Table 2 - Pearson correlation analysis among cow-level information, SCC, milk yield and components and milk ethanol stability Pirasssununga - 2017

\begin{tabular}{|c|c|c|c|c|c|c|c|c|c|c|c|}
\hline \multicolumn{2}{|c|}{ Variables } & MY & Fat & Protein & Lactose & TS & SNF & Casein & NL & LnCCS & DIM $^{7}$ \\
\hline \multirow{2}{*}{$\mathrm{MES}^{1}$} & $r$ & 0.183 & -0.180 & -0.153 & 0.181 & -0.156 & -0.051 & -0.145 & -0.087 & -0.102 & -0.149 \\
\hline & P-valor & 0.0003 & 0.0004 & 0.0023 & 0.0003 & 0.002 & 0.3181 & 0.004 & 0.106 & 0.0443 & 0.006 \\
\hline \multirow{2}{*}{$M Y^{2}$} & $r$ & - & -0.515 & -0.634 & 0.323 & -0.566 & -0.458 & -0.629 & 0.164 & -0.434 & -0.385 \\
\hline & P-valor & - & $<.0001$ & $<.0001$ & $<.0001$ & $<.0001$ & $<.0001$ & $<.0001$ & 0.0022 & $<.0001$ & $<.0001$ \\
\hline \multirow{2}{*}{ Fat } & $r$ & - & - & 0.567 & -0.205 & 0.943 & 0.481 & 0.575 & -0.167 & 0.278 & 0.322 \\
\hline & P-valor & - & - & $<.0001$ & $<.0001$ & $<.0001$ & $<.0001$ & $<.0001$ & 0.002 & $<.0001$ & $<.0001$ \\
\hline \multirow{2}{*}{ Protein } & $r$ & - & - & - & 0.279 & -0.173 & -0.268 & -0.422 & 0.072 & -0.345 & -0.239 \\
\hline & P-valor & - & - & - & $<.0001$ & 0.0006 & $<.0001$ & $<.0001$ & 0.1846 & $<.0001$ & $<.0001$ \\
\hline \multirow{2}{*}{ Lactose } & $r$ & - & - & - & - & 0.943 & 0.481 & 0.575 & -0.167 & 0.277 & 0.322 \\
\hline & P-valor & - & - & - & - & $<.0001$ & $<.0001$ & $<.0001$ & 0.002 & $<.0001$ & $<.0001$ \\
\hline \multirow{2}{*}{$\mathrm{TS}^{3}$} & $r$ & - & - & - & - & - & 0.778 & 0.990 & -0.139 & 0.434 & 0.4157 \\
\hline & P-valor & - & - & - & - & - & $<.0001$ & $<.0001$ & 0.0097 & $<.0001$ & $<.0001$ \\
\hline \multirow{2}{*}{$\mathrm{SNF}^{4}$} & $r$ & - & - & - & - & - & - & -0.486 & 0.163 & -0.387 & -0.282 \\
\hline & P-valor & - & - & - & - & - & - & $<.0001$ & 0.0025 & $<.0001$ & $<.0001$ \\
\hline \multirow{2}{*}{ Casein } & $r$ & - & - & - & - & - & - & - & -0.139 & 0.434 & 0.416 \\
\hline & P-valor & - & - & - & - & - & - & - & 0.0097 & $<.0001$ & $<.0001$ \\
\hline \multirow{2}{*}{$\mathrm{NL}^{5}$} & $r$ & - & - & - & - & - & - & - & - & -0.482 & -0.409 \\
\hline & P-valor & - & - & - & - & - & - & - & - & $<.0001$ & $<.0001$ \\
\hline \multirow{2}{*}{$\operatorname{LnCCS}^{6}$} & $r$ & - & - & - & - & - & - & - & - & - & -0.365 \\
\hline & P-valor & - & - & - & - & - & - & - & - & - & $<.0001$ \\
\hline
\end{tabular}

${ }^{1}$ Milk ethanol stability; ${ }^{2}$ Milk yield; ${ }^{3}$ Total solids; ${ }^{4}$ Solids-non-fat; ${ }^{5}$ Number of lactation; ${ }^{6}$ Somatic cell counts transformed to natural logarithms; ${ }^{7}$ Days in milk

Table 3 - Effect of milk yield and composition, intramammary infection and cow-level information on milk ethanol stability using multivariable mixed regression model - Pirassununga - 2017

\begin{tabular}{|c|c|c|c|c|c|}
\hline \multirow{2}{*}{ Effect } & \multirow{2}{*}{$\boldsymbol{\beta}$} & \multirow{2}{*}{$\mathbf{S E}^{1}$} & \multirow{2}{*}{$P$ - values } & \multicolumn{2}{|c|}{$95 \% \mathrm{CL}$} \\
\hline & & & & Lower & Upper \\
\hline Number of lactation & 0.43 & 0.438 & 0.328 & -0.433 & 1.293 \\
\hline Days in milk & -0.005 & 0.0036 & 0.139 & -0.013 & 0.0018 \\
\hline Front vs. Rear & -0.109 & 0.284 & 0.701 & -0.669 & 0.451 \\
\hline$M Y^{2}, g / q u a r t e r$ & 0.00004 & 0.00008 & 0.64 & -0.00012 & 0.00020 \\
\hline Fat, $\mathrm{g} / \mathrm{kg}$ & -0.043 & 0.0328 & 0.192 & -0.108 & 0.022 \\
\hline Protein, $\mathrm{g} / \mathrm{kg}$ & -0.647 & 0.389 & 0.097 & -0.119 & 1.413 \\
\hline Lactose, $\mathrm{g} / \mathrm{kg}$ & 0.218 & 0.084 & $0.009^{*}$ & 0.053 & 0.383 \\
\hline Casein, $\mathrm{g} / \mathrm{kg}$ & -0.782 & 0.390 & $0.046^{*}$ & -1.55 & -0.013 \\
\hline $\operatorname{Ln} \mathrm{CCS}^{3}$ & 0.105 & 0.138 & 0.445 & -0.166 & 0.375 \\
\hline Negative vs. contagious & -1.068 & 2.081 & 0.608 & -5.165 & 3.030 \\
\hline Negative vs. environmental & -0.218 & 0.521 & 0.675 & -1.244 & 0.807 \\
\hline Negative vs. minor & 0.704 & 0.445 & 0.115 & -0.173 & 1.580 \\
\hline Negative vs. infrequent & -0.269 & 0.787 & 0.733 & -1.819 & 1.282 \\
\hline
\end{tabular}


Effect of IMI at the mammary quarter level on MES

Two models were tested using the comparison between mammary quarters. Healthy vs. infected quarters were evaluated in model 1, and no effect of IMI was observed on MES. Model 2 evaluated the comparison between contralateral healthy and infected mammary quarters clustered within the cow with the result that there was also no effect of IMI observed on MES. Infected quarters according to groups of pathogens (major, minor and infrequent pathogens; or contagious, environmental, minor and infrequent) were compared with healthy contralateral mammary quarters. Similarly, there was no effect of IMI according to pathogen groups on MES in both models (Table 4).

Table 4 - Effect of subclinical intramammary infection on milk ethanol stability using contralateral mammary quarter comparison - Pirassununga - 2017

\begin{tabular}{|c|c|c|c|c|c|}
\hline \multirow{2}{*}{ Item } & \multirow{2}{*}{ MES $^{1}$} & \multirow{2}{*}{$\mathrm{SE}^{2}$} & \multicolumn{3}{|c|}{ P-values } \\
\hline & & & Halves $^{3}$ & Pathogen & Interaction $^{4}$ \\
\hline \multicolumn{6}{|l|}{ Model - 1} \\
\hline Cluster 1 - Negative vs. Infected & & & 0.889 & 0.592 & 0.840 \\
\hline Infected & 76.185 & 0.907 & - & - & - \\
\hline Negative & 76.135 & 0.882 & - & - & - \\
\hline Cluster 2 - Negative vs. Infected & & & 0.677 & 0.723 & 0.977 \\
\hline Major & 76.124 & 0.988 & - & - & - \\
\hline Minor & 76.496 & 0.972 & - & - & - \\
\hline Infrequent & 75.400 & 1.156 & - & - & - \\
\hline Negative & 76.137 & 0.884 & - & - & - \\
\hline Cluster 3 - Negative vs. Infected & & & 0.742 & 0.142 & 0.158 \\
\hline Contagious & 76.697 & 1.331 & - & - & - \\
\hline Environmental & 75.806 & 1.028 & - & - & - \\
\hline Minor & 76.453 & 0.996 & - & - & - \\
\hline Negative & 76.117 & 0.911 & - & - & - \\
\hline Infrequent & 75.347 & 1.276 & - & - & - \\
\hline \multirow[t]{2}{*}{ Model - 2} & \multicolumn{5}{|c|}{ Comparing contralateral quarters } \\
\hline & Difference & SE & & & \\
\hline Cluster 1 - Negative vs. Infected & & & 0.375 & 0.907 & 0.398 \\
\hline Negative vs. Infected & 0.238 & 0.411 & - & 0.564 & - \\
\hline Negative vs. Negative ${ }^{5}$ & 0.175 & 0.349 & - & 0.618 & - \\
\hline Cluster 2 - Negative vs. Infected & & & 0.415 & 0.742 & 0.409 \\
\hline Negative vs. Major & 0.230 & 0.660 & - & 0.727 & - \\
\hline Negative vs. Minor & 0.020 & 0.660 & - & 0.976 & - \\
\hline Negative vs. Infrequent & 1.224 & 0.937 & - & 0.194 & - \\
\hline Negative vs. Negative & 0.175 & 0.350 & - & 0.618 & - \\
\hline Cluster 3 - Negative vs. Infected & & & 0.438 & 0.662 & 0.281 \\
\hline Negative vs. Contagious & -1.333 & 1.532 & - & 0.386 & - \\
\hline Negative vs. Environmental & 0.828 & 0.666 & - & 0.216 & - \\
\hline Negative vs. Minor & 0.020 & 0.657 & - & 0.976 & - \\
\hline Negative vs. Negative & 0.175 & 0.350 & - & 0.617 & - \\
\hline Negative vs. Infrequent & 0.98 & 1.126 & - & 0.385 & - \\
\hline
\end{tabular}

${ }^{1}$ Milk ethanol stability; ${ }^{2}$ Standard error; ${ }^{3}$ Front and rear quarters; ${ }^{4}$ Interaction between group of pathogens and quarter position; ${ }^{5}$ Right healthy quarters were consistently subtracted from left healthy contralateral quarters 


\section{Discussion}

The comparison between contralateral mammary quarters clustered within cow was used as an attempt to reduce the confounding factors at both cow and herd level, such as the cow's nutritional, metabolic and immune status, genetic predisposition, management systems and/or environmental challenge, which were previously associated with MES (FISCHER et al., 2012). To test the hypothesis formulated in the present study, we evaluated the effect of IMI, in a natural exposure trial, on MES by using a comparison between infected and healthy contralateral mammary quarters of dairy cows. The obtained results indicated that the occurrence of IMI did not alter MES when healthy and infected contralateral mammary quarters were compared. The same result occurred when the IMI according to groups of pathogens (major, minor and infrequent; or contagious, environmental, minor and infrequent) were included in the model. These results suggested that subclinical IMI are not associated with occurrence of unstable non-acid milk using the alcohol test for evaluation of milk stability.

Mastitis was previously associated with changes in milk components (reduction of lactose and casein contents and increase of non-casein fraction and ions concentration) due to the reduction in synthesis capacity of mammary cells, and increased permeability of mammary gland cells tight junctions (OGOLA et al., 2007). The increase of milk concentration of ionic calcium was the most principal factor associated with the reduction of casein micelles stability. When milk concentrations of iCa increased, a reduction was noted in the negative charges of casein micelles and in electrostatic repulsion forces between them, facilitating the micelle interactions and reducing the MES (JEURNINK; KRUIF, 1995; BARROS et al., 1999). However, no effect of subclinical IMI on MES was found.

Milk fat content is usually unchanged in milk from mastitis infected cows (BUENO et al., 2005). However, milk crude protein content is generally affected by mastitis with a reduction of the concentration of casein and increase of whey proteins in milk, which was associated with proteins mainly prevenient from blood (albumin and immunoglobulin) (KITCHEN, 1981). Additionally, the reduction of lactose concentration was associated with mastitis due to the reduction of secretory capacity and influx of lactose from milk to blood (KITCHEN, 1981; AULDIST et al., 1995). In the present study, a positive association between lactose content and MES was found, but the changes of milk composition connected with subclinical mastitis are probably not sufficient to alter the stability of milk proteins at the ethanol test.

Fischer et al. (2012) also did not report association between mastitis and MES. However, Oliveira et al. (2013) reported lower MES of milk with high SCC $\left(\mathrm{SCC}>500 \times 10^{3} \mathrm{cel} / \mathrm{mL}\right)$ than milk with low SCC. Feagan et al. (1966) evaluated the effects of subclinical mastitis on milk heat stability at $140^{\circ} \mathrm{C}$ and found a lower milk heat stability in quarters with subclinical mastitis than in healthy quarters. In the present study, a low frequency of contagious pathogens (1.26\%) was observed using contralateral mammary quarters comparison, since it was the only group of pathogens that showed a negative regression coefficient ( $\beta=-1.333)$. However, the finding was not statistically significant $(P=0.386$; Table 4$)$. For that reason, future studies must be performed to evaluate the effect of contagious pathogens on MES by using a higher number of contralateral mammary quarters. Thus, it is noteworthy that factors such as sample size, absence of duplicate milk sampling for microbiological analysis, and the possibility a potential carry-over effect of previous clinical mastitis may be considered as limitations of the present study.

Previous studies reported that other factors might affect milk composition and MES. Nutrient deficiency was one of the main factors associated with instability of milk proteins at the alcohol test (ZANELA et al., 2006; BARBOSA et al., 2012; STUMPF et al., 2013). Stumpf et al. (2013) reported that feed restriction may increase the permeability of mammary gland cell tight junctions and reduce MES due to saline imbalance. Martins et al. (2015) and Marques et al. (2011) observed that blood acidification increases milk concentration of $\mathrm{iCa}$ and reduces MES, suggesting that ruminal and metabolic acidosis, heat stress, and reduction in dietary cation-anion differences may reduce MES. Thus, the occurrence of unstable nonacid milk in Brazil and other countries that routinely use ethanol test for milk evaluation can be closely associated with nutrient imbalance, digestive disturbances, as well as genetic and environmental conditions, but not with subclinical IMI. Subclinical IMI has no effect on MES when comparing infected and healthy contralateral mammary quarters from dairy cows. This suggests that unstable non-acid milk occurrence is due to other factors that were not evaluated at the present study, such as nutrient 
deficiency and digestive disturbances, as well as genetic and environmental conditions.

\section{Acknowledgments}

This project was supported by São Paulo Research Foundation (Fapesp), Brazil (grant no. 2014/17411-6). Cristian Marlon de Magalhães Rodrigues Martins and Juliano Leonel Gonçalves received a scholarship (grant no. 2015/03942-2 and 2013/23613-8, respectively) from Fapesp during the development of this project.

\section{References}

AULDIST, M. J.; COATS, S.; ROGERS, G. L.; MCDOWELL, G. H. Changes in the composition of milk from healthy and mastitic dairy cows during the lactation cycle. Australian Journal of Experimental Agriculture, v. 35, n. 4, p. 427436, 1995. doi: 10.1071/EA9950427.

BARBOSA, R. S.; FISCHER, V.; RIBEIRO, M. E. R.; ZANELA, M. B.; STUMPF, M. T.; KOLLING, G. J.; SCHAFHÄUSER JÚNIOR, J.; BARROS, L. E.; EGITO, A. S. Caracterização eletroforética de proteínas e estabilidade do leite em vacas submetidas à restrição alimentar. Pesquisa Agropecuária Brasileira, v. 47, n. 4, p. 621-628, 2012. doi: 10.1590/S0100-204X2012000400019.

BARROS, L. M.; DENIS, N.; GONZÁLEZ, M. A.; NUÑEZ, A. Prueba del alcohol em leche y relación con calcio iónico. Revista Prácticas Veterinarias, v. 9, n. 2, p. 315, 1999.

BUENO, V. F. F.; MESQUITA, A. J.; NICOLAU, E. S.; OLIVEIRA, A. N.; OLIVEIRA, J. P.; NEVES, R. B. S.; MANSUR, J. R. G.; THOMAZ, L. W. Contagem celular somática: relação com a composição centesimal do leite e período do ano no Estado de Goiás. Ciência Rural, v. 35, n. 4, p. 848-854, 2005. doi: 10.1590/S0103-84782005000400016.

CHAVEZ, M. S.; NEGRI, L. M.; TAVERNA, M. A.; CUATRÍN, A. Bovine milk composition parameters affecting the ethanol stability. The Journal of Dairy Research, v. 71, n. 2, p. 201-206, 2004. doi: 10.1017/ S0022029904000172.

DOHOO, I.; ANDERSEN, S.; DINGWELL, R.; HAND, K.; KELTON, D.; LESLIE, K.; SCHUKKEN, Y.; GODDEN, S. Diagnosing intramammary infections: comparison

\section{Statement of animal rights}

All experimental procedures were approved by the Ethical Committee for the Use of Animals at the School of Veterinary Medicine and Animal Science at the University of São Paulo, Brazil (protocol number 3020/2013).

\section{Conflict of interest statement}

The author(s) declare(s) that there is no conflict of interest regarding the publication of this article.

of multiple versus single quarter milk samples for the identification of intramammary infections in lactating dairy cows. Journal of Dairy Science, v. 94, n. 11, p. 55155522, 2011a. doi: 10.3168/jds.2011-4486.

DOHOO, I.; SMITH, J.; ANDERSEN, S.; KELTON, D. F.; GODDEN, S.; MASTITIS RESEARCH WORKERS' CONFERENCE. Diagnosing intramammary infections: evaluation of definitions based on a single milk sample. Journal of Dairy Science, v. 94, n. 1, p. 250-261, 2011 b. doi: 10.3168/jds.2010-3559.

FAGNANI, R.; BELOTI, V.; BATTAGLINI, A. P. P. Acidbase balance of dairy cows and its relationship with alcoholic stability and mineral composition of milk. Pesquisa Veterinária Brasileira, v. 34, n. 5, p. 398-402, 2014. doi: 10.1590/S0100-736X2014000500002.

FEAGAN, J. T.; GRIFFIN, A. T.; LLOYD, G. T. Effects of subclinical mastitis on heat stability of fluid milk. Journal of Dairy Science, v. 49, n. 8, p. 933-939, 1966. doi: 10.3168/ jds.S0022-0302(66)87984-5.

FISCHER, V.; RIBEIRO, M. E. R.; ZANELA, M. B.; MARQUES, L. T.; ABREU, A. S.; MACHADO, S. C.; FRUSCALSO, V.; BARBOSA, R. S.; STUMPF, M. T. Unstable non acid milk: a solvable problem? Revista Brasileira de Saúde e Produção Animal, v. 13, n. 3, p. 838-849, 2012. doi: 10.1590/S1519-99402012000300021.

GONÇALVES, J. L. Impact of subclinical mastitis on milk yield and economic return of dairy cows. 2017. $149 \mathrm{f}$. Tese (Doutorado) - Faculdade de Medicina Veterinária e Zootecnia, Universidade de São Paulo, São Paulo, 2017. 
GONÇALVES, J. L.; TOMAZI, T.; BARREIRO, J. R.; BEURON, D. C.; ARCARI, M. A.; LEE, S. H. I.; ARAÚJO JUNIOR, J. P.; SANTOS, M. V. Effects of bovine subclinical mastitis caused by Corynebacterium spp. on somatic cell count, milk yield and composition by comparing contralateral quarters. The Veterinary Journal, v. 209, p. 87-92, 2016. doi: 10.1016/j.tvj1.2015.08.009.

HOLT, C. An equilibrium thermodynamic model of the sequestration of calcium phosphate by casein micelles and its application to the calculation of the partition of salts in milk. European Biophysics Journal, v. 33, n. 5, p. 421-434, 2004. doi: 10.1007/s00249-003-0377-9.

JEURNINK, T. J. M.; KRUIF, K. G. Calcium concentration in milk in relation to heat stability and fouling. Netherlands Milk and Dairy Journal, v. 49, n. 2-3, p. 151-165, 1995.

KITCHEN, B. J. Bovine mastitis: milk compositional changes and related diagnostic tests. Journal of Dairy Research, v. 48, n. 1, p. 167-188, 1981. doi: 10.1017/ S0022029900021580.

LEITNER, G.; KRIFUCKS, O.; MERIN, U.; LAVI, Y.; SILANIKOVE, N. Interactions between bacteria type, proteolysis of casein and physico-chemical properties of bovine milk. International Dairy Journal, v. 16, n. 6, p. 648-654, 2006. doi: 10.1016/j.idairyj.2005.10.020.

LEWIS, M. J. The measurement and significance of ionic calcium in milk: a review. International Journal of Dairy Technology, v. 64, n. 1, p. 1-13, 2011. doi: 10.1111/j.14710307.2010.00639.x.

MARQUES, L. T.; FISCHER, V.;ZANELA, M. B.; RIBEIRO, M. E. R.; STUMPF JUNIOR, W.; RODRIGUES, C. M. Produção leiteira, composição do leite e perfil bioquímico sanguíneo de vacas lactantes sob suplementação com sal aniônico. Revista Brasileira de Zootecnia, v. 40, n. 5, p. 1088-1094, 2011. doi: 10.1590/S1516-35982011000500021.

MARTINS, C. M. R.; ARCARI, M. A.; WELTER, K. C.; NETTO, A. S.; OLIVEIRA, C. A. F.; SANTOS, M. V. Effect of dietary cation-anion difference on performance of lactating dairy cows and stability of milk proteins.
Journal of Dairy Science, v. 98, n. 4, p. 2650-2661, 2015. doi: 10.3168/jds.2014-8926.

NATIONAL MASTITIS COUNCIL (NMC). Microbiological procedures for the diagnosis of bovine udder infection and determination of milk quality. 4. ed. Verona: NMC, 2004. 47 p.

OGOLA, H.; SHITANDI, A.; NANUA, J. Effect of mastitis on raw milk compositional quality. Journal of Veterinary Science, v. 8, n. 3, p. 237-242, 2007. doi: 10.4142/jvs.2007.8.3.237.

OLIVEIRA, C. A. F.; LOPES, L. C.; ROSIM, R. E.; FERNANDES, A. M.; CORASSIN, C. H.; CORASSIN, C. $\mathrm{H}$. Composition, somatic cell count and casein fractions of ethanol unstable milks. Acta Scientiarum: Technology, v. 35, n. 1, p. 153-156, 2013. doi: 10.4025/actascitechnol.v35i1.11481.

SINGH, H. Heat stability of milk. International Journal of Dairy Technology, v. 57, n. 2-3, p. 111-119, 2004. doi: 10.1111/j.1471-0307.2004.00143.x.

STATISTICAL ANALYSIS SYSTEM INSTITUTE (SAS). Statistical analysis user's guide. Version 8.2. Cary: SAS, 2001. 1686 p.

STUMPF, M. T.; FISCHER, V.; MCMANUS, C. M.; KOLLING, G. J.; ZANELA, M. B.; SANTOS, C. S.; ABREU, A. S.; MONTAGNER, P. Severe feed restriction increases permeability of mammary gland cell tight junctions and reduces ethanol stability of milk. Animal, v. 7, n. 7, p. 11371142, 2013. doi: 10.1017/S1751731113000128.

TSIOULPAS, A.; GRANDISON, A. S.; LEWIS, M. J. Changes in physical properties of bovine milk from the colostrum period to early lactation. Journal of Dairy Science, v. 90, n. 11, p. 5012-5017, 2007. doi: 10.3168/jds.2007-0192.

ZANELA, M. B.; FISCHER, V.; RIBEIRO, M. E. R.; BARBOSA, R. S.; MARQUES, L. T.; STUMPF JUNIOR, W.; ZANELA, C. Leite instável não-ácido e composição do leite de vacas Jersey sob restrição alimentar. Pesquisa Agropecuária Brasileira, v. 41, n. 5, p. 835-840, 2006. doi: 10.1590/S0100-204X2006000500016. 